\title{
New floristic records from Central Europe 4 (reports 41-53)
}

\author{
Matej Dudáš ${ }^{1}$ (ed.), Miroslava Malovcová-Staníková², Artur Pliszko³, \\ Branislav Schieber ${ }^{4}$, Jerzy Zieliński ${ }^{5}$
}

\begin{abstract}
${ }^{1}$ Department of Botany, Institute of Biology \& Ecology, Faculty of Science, P. J. Šafárik University, Mánesova 23, SK-041 54 Košice, Slovakia, matej.dudas@upjs.sk

${ }^{2}$ Homeland museum Hlohovec, Františkánske námestie 1, SK-920 01 Hlohovec, Slovakia, malovcova.miroslava@zupa-tt.sk

${ }^{3}$ Institute of Botany, Faculty of Biology, Jagiellonian University, Gronostajowa 3, 30-387 Kraków, Poland, artur.pliszko@uj.edu.pl

${ }^{4}$ Institute of Forest Ecology, Slovak Academy of Sciences, L'. Štúra 2, SK-960 53, Zvolen, Slovakia, schieber@ife.sk

Institute of Dendrology, Polish Academy of Sciences, Parkowa 5, 62-035 Kórnik, Poland, jeziel@man.poznan.pl
\end{abstract}

Dudáš, M., Malovcová-Staníková, M., Pliszko, A., Schieber, B. \& Zieliński, J. (2019): New floristic records from Central Europe 4 (reports 41-53). - Thaiszia - J. Bot. 29 (2): 231-237

\begin{abstract}
The fourth part of the series includes 13 new chorological records of vascular plants from Poland and Slovakia. From Poland, the first record of Rubus austroslovacus from the Vistula River valley is given as well as the first record of Erigeron $\times$ huelsenii from Silesia. Beside this, spontaneous occurrence of Portulaca grandiflora in Kraków and P. oleracea subsp. oleracea in Suwałki has been recorded outside the cultivation. In Slovakia, new sites of endangered species Dichostylis micheliana and Stipa pulcherrima were found as well as new distribution data about Sonchus palustris and Reynoutria japonica. From railway stations, Tribulus terrestris is reported for the first time from eastern Slovakia likewise two new sites of alien species Euphorbia davidii, previously reported from only single locality in southeastern Slovakia. Alien species Xanthium spinosum was reported from the Štiavnické vrchy Mts. and also Sisyrinchium montanum in the Slanské vrchy Mts. Third report of Sagittaria latifolia in Slovakia is given with short characteristic of its coenological conditions.
\end{abstract}

Keywords: chorology, vascular plants, alien species, Slovakia, Poland, new reports, Red list species, railway station.

This is an ongoing report in the established series dealing with the new chorological data on higher vascular plants in Central Europe (for details, see Thaiszia - J. Bot. 28 (1), pp. 79-80, 2018). The nomenclature of taxa follows 
the Euro+Med PlantBase (Euro+Med 2006-) and/or Checklist of non-vascular and vascular plants of Slovakia (Marhold \& Hindák 1998), herbarium acronyms follow Thiers (2019+).

The publication includes contributions by M. Dudáš (41-46), M. MalovcováStaníková (47-48), A. Pliszko (49-51), A. Pliszko \& J. Zieliński (52) and B. Schieber (53) arranged alphabetically.

\section{Matej Dudáš (reports 41-46)}

\section{$\underline{\text { SK }}$}

41. Dichostylis micheliana (L.) Nees: the Východoslovenská nížina lowland, lžkovce, Laborec River, sandy island in river bed under weir (near the Vojany power plant), 2 plants, $103 \mathrm{~m}, 48^{\circ} 33^{\prime} 46.6^{\prime \prime} \mathrm{N} 21^{\circ} 57^{\prime} 44.1^{\prime \prime} \mathrm{E}, 7497 \mathrm{~b}, 26.8$. 2019, M. Dudáš, photodocumented. - Brehov, Latorica River, former sandy beach, frequent, $105 \mathrm{~m}, 48^{\circ} 28^{\prime} 27.9^{\prime \prime} \mathrm{N} 21^{\circ} 50^{\prime} 34.3^{\prime \prime} \mathrm{E}, 7597 \mathrm{a}, 25$. 8. 2019, M. Dudáš, KO 34875. - Brehov, Latorica River, sandy-clay silt under high bank, close to dead oxbow “Merčány", 2 plants, 98 m, 48²9'19.7"N 2151'41.7"E, 7597a, 31. 8. 2019, M. Dudáš, observation. - Malé Trakany, Tisa River, sandy beach, 3 plants, $100 \mathrm{~m}, 48^{\circ} 23^{\prime} 38.6^{\prime \prime} \mathrm{N} 22^{\circ} 08^{\prime} 34.9^{\prime \prime} \mathrm{E}, 7698 \mathrm{~b}, 19.9 .2019$, M. Dudáš, observation.

In south-eastern Slovakia, $D$. micheliana is typical plant of periodical wet habitats distributed along large lowland rivers. In the Red List of Slovakia this species is classified as endangered (EN) and is protected by law (Eliás et al. 2015). Several recent data on the occurrence of this species, with summary on its historical and recent distribution in Slovakia were previously published by Dítětová et al. (2016).

42. Euphorbia davidii Subils: the Východoslovenská nížina lowland, Bánovce nad Ondavou, railway station, numerous population between railway tracks on south-western end of platform, on gravel, $118 \mathrm{~m}, 48^{\circ} 40^{\prime} 46.9^{\prime \prime} \mathrm{N} 21^{\circ} 50^{\prime} 06.6^{\prime \prime} \mathrm{E}$, 7397a, 5. 10. 2019, M. Dudáš, KO 34879, photodocumented (Fig. 1). - Trebišov, NE edge of the city (stop Trebišov ŠRT), crossing the railway track, infrequent, ca $102 \mathrm{~m}, 48^{\circ} 38^{\prime} 25.6^{\prime \prime} \mathrm{N} 21^{\circ} 43^{\prime} 44.0^{\prime \prime} \mathrm{E}, 5$. 10. 2019, 7396c, M. Dudáś, KO 34878.

The species was firstly reported in 2012 only from single locality in southeastern Slovakia (Jehlík et al. 2013).

43. Sagittaria latifolia Willd.: the Slanské vrchy Mts., Vyšná Kamenica, frequent on the banks of fishpond Vyšná Kamenica, $387 \mathrm{~m}, 48^{\circ} 47^{\prime} 15.2^{\prime \prime} \mathrm{N} 21^{\circ} 29^{\prime} 12.2^{\prime \prime} \mathrm{E}$, 7294b, June 2015 and 16. 8. 2019, M. Dudáš, KO 34871, BRNU 671091, relevé 1.

Third record in Slovakia. This American species was observed for the first time in southern Slovakia near Horný Badín village in 2013 and on the bank of Ipel' River near Salka village in 2017 respectively (Nobis et al. 2019). The new discovered population was found already in 2015 (Fig. 2) and spontaneously spreads throughout the littoral zone of the fishpond in Vyšná Kamenica. The origin seems to be unknown, the locality is irregularly mowed by fisherman. S. latifolia 


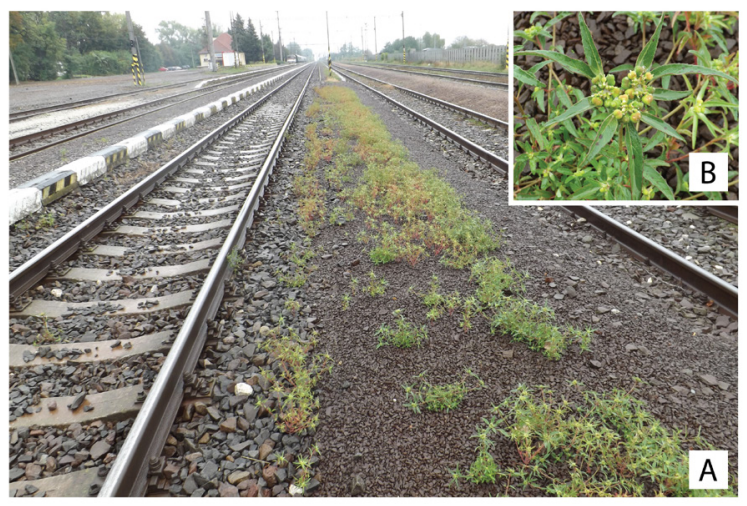

Fig. 1. Population of Euphorbia davidii between railway tracks at the railway station Bánovce nad Ondavou (A), detail of cyathium (B). Photographed by M. Dudáš.

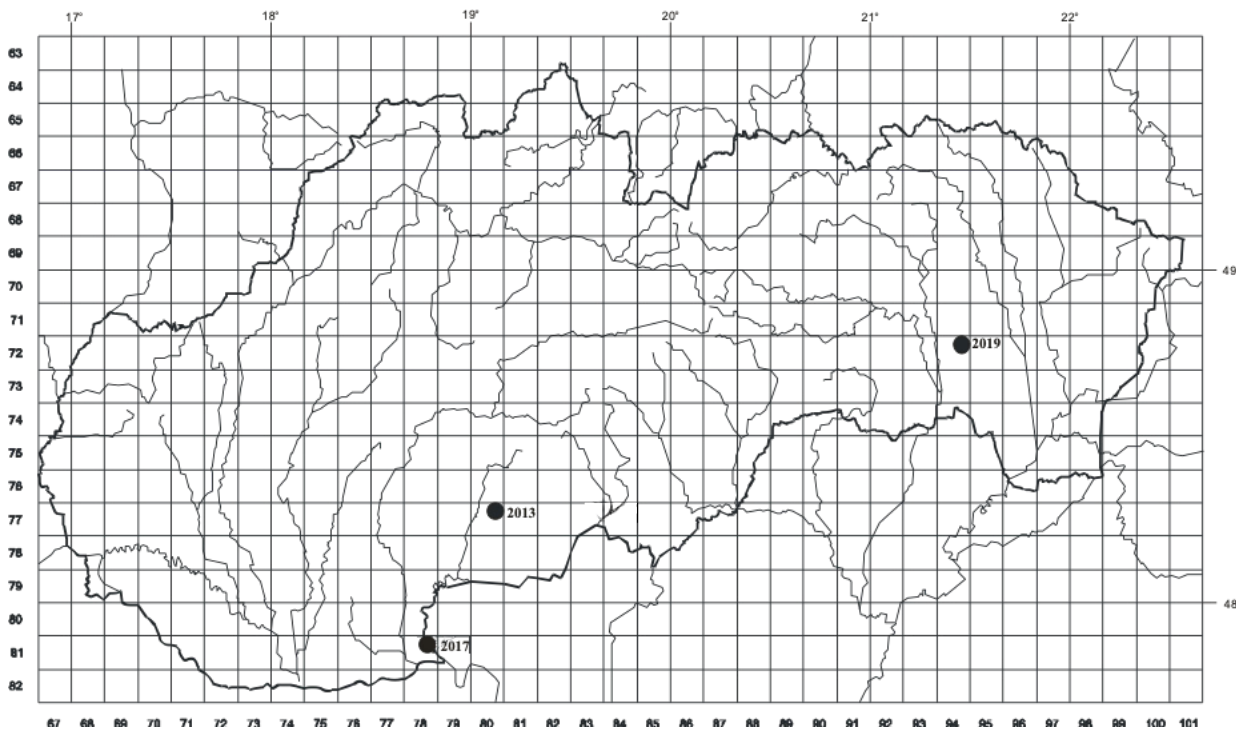

Fig. 2. Sagittaria latifolia in Slovakia, new record (2019) and previously published localities with year of its first record (modified according to Nobis et al. 2019).

grows there within typical native marshy vegetation in four micropopulations, the largest one reaches the area of $10 \times 4 \mathrm{~m}$. This vegetation is characterized by the following phytosociological relevé (no. 1).

Relevé 1. Eastern Slovakia, the Slanské vrchy Mts., Vyšná Kamenica village, fishpond, littoral zone in southwestern edge of fishpond, $16 \mathrm{~m}^{2}, 48^{\circ} 47^{\prime} 15.2^{\prime \prime} \mathrm{N}$ 2129'12.2"E, 387 m a.s.l., elev. -, exp. -, E1: 98\%, 21. 8. 2019, M. Dudáš.

E1: Sagittaria latifolia 5, Typha angustifolia $2 \mathrm{~m}$, Scirpus sylvaticus 1, Lycopus europaeus + , Scutellaria galericulata + , Lysimachia nummularia + , Myosotis palustris + , Calystegia sepium r. 
44. Sisyrinchium montanum Greene: the Slanské vrchy Mts., Zlatá Baňa, saddle Temný les, wet edge of field road under small fen, five clusters with 3 flowering plants and 5 after blossom, ca $683 \mathrm{~m}, 48^{\circ} 56^{\prime} 28.0^{\prime \prime} \mathrm{N} 21^{\circ} 26^{\prime} 17.4^{\prime \prime} \mathrm{E}, 7094 \mathrm{~d}, 9.6$. 2019, M. Dudáš, KO 34827, photodocumented.

New report from northern part of the Slanské vrchy Mts. Previous occurrence published by Murín \& Májovský (1976) was based on herbarium specimen collected by L'. Dostál (deposited at SLO) from fen near the village of Banské in the central part of the mountain. The species is reported very rare in eastern Slovakia. Known also from the Bukovské vrchy Mts. (Hadač \& Terray 1991; Valachovič 1997 unpublished data).

45. Stipa pulcherrima K. Koch: the Slanské vrchy Mts., Kapušany (near Prešov), southern xerothermous andesite hillside of the castle hill, at tourist path towards Kapušiansky hrad castle, straggle occurrence, ca $400 \mathrm{~m}, 49^{\circ} 03^{\prime} 11.1^{\prime \prime} \mathrm{N}$ $21^{\circ} 19^{\prime} 16.9^{\prime \prime} E, 6993 b, 2$. 6. 2019, M. Dudáš, NI, revised by P. Eliáš jun.

It is only single locality of its occurrence in the Slanské vrchy Mts. In the Red List of Slovakia this species is classified as near threatened (NT) and is protected by law (Eliáš et al. 2015).

46. Tribulus terrestris L: the Východoslovenská nížina lowland, Strážske, railway station, in the first track between sleepers, only single plant in gravel, 132 $\mathrm{m}, 48^{\circ} 52^{\prime} 02.5^{\prime \prime} \mathrm{N} 21^{\circ} 49^{\prime} 30.4^{\prime \prime} \mathrm{E}, 7196 \mathrm{~b}, 28$. 9. 2019, M. Dudáš, KO 34874 . Bánovce nad Ondavou, railway station, frequent on platforms, in gravel, $118 \mathrm{~m}$, $48^{\circ} 40^{\prime} 46.9^{\prime \prime} \mathrm{N} 21^{\circ} 50^{\prime} 06.6^{\prime \prime} \mathrm{E}, 7397 \mathrm{a}, 28$. 9. 2019, M. Dudáš, KO 34873, 34881.

This two reports seem to be the easternmost, and at the same time the first findings from eastern Slovakia. In the past, the species was relatively rare with the distribution only in south-western Slovakia, but in the present it spreads very intensively across country by railway traffic to secondary habitats (Májeková et al. 2014).

\section{Miroslava Malovcová-Staníková (reports 47-48)}

\section{$\underline{\text { SK }}$}

47. Reynoutria japonica Houtt.: the Považský Inovec Mts., Tepličky, Valbruch Land area, deserted quarry, ca. $1,5 \mathrm{~km}$ NW of the village, $300 \mathrm{~m}, 48^{\circ} 28^{\prime} 23.9^{\prime \prime} \mathrm{N}$ $17^{\circ} 50^{\prime} 28.3^{\prime \prime E}, 7573 a, 9.8 .2019$, M. Malovcová, record. - the Považský Inovec Mts., Horné Otrokovce, deserted quarry near the village, $260 \mathrm{~m}, 48^{\circ} 29^{\prime} 39.5^{\prime \prime} \mathrm{N}$ $17^{\circ} 52^{\prime} 28^{\prime \prime} \mathrm{E}, 7573 a, 16$. 8. 2019, M. Malovcová, record. - the Nitrianska pahorkatina Hills, Tekold'any, SE of the village, near the field road to Urbáre Land area, $200 \mathrm{~m}, 48^{\circ} 29^{\prime} 23.5^{\prime \prime} \mathrm{N} 17^{\circ} 54^{\prime} 27.3^{\prime \prime} \mathrm{E}, 7573 a, 16$. 8. 2019, M. Malovcová, record.

48. Sonchus palustris L.: the Nitrianska pahorkatina Hills, Merašice, $W$ of the village, brook Stoličný potok, $160 \mathrm{~m}, 48^{\circ} 27^{\prime} 46.1^{\prime \prime} \mathrm{N} 17^{\circ} 56^{\prime} 27.0^{\prime \prime} \mathrm{E}, 7573 \mathrm{~b}, 5.9$. 2019, M. Malovcová, photodocumented. 
The species was firstly reported from this locality in 2009 with small number of individuals (Kollár et al. 2009). In September 2019 vital population consisting of approximately fifty plants was confirmed there.

\section{Artur Pliszko (reports 49-51)}

$\underline{P L}$

49. Erigeron xhuelsenii Vatke: southern Poland, Silesia, Zabrze, one flowering plant on a sandy roadside, near the railway track, among parental species, 258 $\mathrm{m}, 50^{\circ} 18.390^{\prime} \mathrm{N} 18^{\circ} 48.568^{\prime} \mathrm{E}, 26.8$. 2017, A. Pliszko, KRA 0474683.

Erigeron $\times$ huelsenii, a natural hybrid between the North American E. canadensis L. and the Eurasian E. acris L. s. str., occurs in Europe with several dozen records from the United Kingdom, Belgium, Germany, the Czech Republic, Slovakia, Poland, and Russia (Pliszko \& Kostrakiewicz-Gierałt 2018 and references therein). It is usually found in anthropogenic habitats such as abandoned sand and gravel quarries, disused ironworks, roadside verges, railway areas and arable fields with grass-legume mixtures (Pliszko \& Jaźwa 2017; Pliszko \& KostrakiewiczGierałt 2018 and references therein). It possesses intermediate morphological characters between its parental species and cannot produce normal fruits with viable seeds (Pliszko \& Kostrakiewicz-Gierałt 2018). In Poland, the hybrid has been confirmed with 10 localities in the north-western, north-eastern and central-eastern parts of the country so far. It is treated as a casual alien species in the Polish flora. This is the first record of E. xhuelsenii from Silesia, southern Poland.

50. Portulaca grandiflora Hook.: southern Poland, Lesser Poland Province, Kraków, one flowering plant in the gap between the pavement tiles, near the wall of the building, $218 \mathrm{~m}, 50^{\circ} 02.532^{\prime} \mathrm{N} 19^{\circ} 56.633^{\prime} \mathrm{E}, 16$. 7. 2019, A. Pliszko, KRA 0518717.

The species is native to South America (Matthews \& Levins 1985). In Poland, it is cultivated in gardens and cemeteries (Mirek et al. 2002; Czarna \& Nowińska 2011; Jędrzejko et al. 2013). Moreover, it is often planted in pots and placed on balconies. This is the first record of its spontaneous occurrence outside the cultivation site in Kraków, Lesser Poland Province. Currently, it should be classified as a casual alien species in the Polish flora.

51. Portulaca oleracea subsp. oleracea L.: north-eastern Poland, Lithuanian Lakeland, Suwałki, several fruiting individuals on a trampled lawn, $175 \mathrm{~m}$, $54^{\circ} 05.767^{\prime} \mathrm{N} 22^{\circ} 56.519^{\prime} \mathrm{E}, 5.8 .2019$, A. Pliszko, KRA 0518716.

The species is native to South Asia and North Africa. In Poland, it is an established alien (kenophyte) occurring in anthropogenic habitats (Tokarska-Guzik et al. 2012). It is a very rare species in the north-eastern part of the country. This is the first record of its occurrence in the Polish part of the Lithuanian Lakeland. 


\section{Artur Pliszko \& Jerzy Zieliński (report 52)}

$\underline{P L}$

52. Rubus austroslovacus Trávn.: southern Poland, Lesser Poland Province, Kraków, several dozen flowering plants in the roadside shrubbery, near the Vistula River, $203 \mathrm{~m}, 50^{\circ} 03.119^{\prime} \mathrm{N} 19^{\circ} 58.574^{\prime} \mathrm{E}, 2$. 7. 2019, A. Pliszko, KRA (0522034-0522039).

The species is native to Central Europe. It has been reported from Germany (SE part), the Czech Republic, Slovakia, Lower Austria, and Poland so far (Trávníček \& Zázvorka 2005; Kurtto \& Weber 2009). In Poland, it occurs mostly in the southwestern part of the country (Zieliński et al. 2004; Kosiński 2010). Moreover, it is treated as a locally endangered species in the Bardo Mts, Central Sudetes (Kosiński 2010). This is the first record of $R$. austroslovacus from the Vistula River valley in Lesser Poland Province.

\section{Branislav Schieber (report 53)}

$\underline{\text { SK }}$

53. Xanthium spinosum L.: Štiavnické vrchy Mts., Krupina district, Žibritov, three plants with ripening fruits on a terrace among grassland near the village, sheep grazing, $470 \mathrm{~m}, 48^{\circ} 23^{\prime} 10.3^{\prime \prime} \mathrm{N} 18^{\circ} 59^{\prime} 32.4^{\prime \prime} \mathrm{E}, 7679 \mathrm{~b}, 4.11 .2018$, B. Schieber, photodocumentation.

Note of editor: in the past rare introduced in central Slovakia and recent distribution data are missing.

\section{Acknowledgement}

Thank to M. Valachovič (Bratislava, Slovakia) for providing his unpublished floristic record and T. Miháliková (Bratislava, Slovakia) for creating the map.

\section{References}

Czarna A. \& Nowińska R. (2011): Vascular flora in cemeteries of the Roztocze region and surrounding areas (south-east Poland). - Acta Agrobot. 64(2): 77-92. DOI: https:// doi.org/10.5586/aa.2011.020

Dítětová Z., Dítě D., Letz D. R. \& Eliáš P. jun. (2016): New records of rare species on exposed river banks and pools in southern Slovakia. - Thaiszia - J. Bot. 26/1: 57-75.

Eliáš P. jun., Dítě D., Kliment J., Hrivnák R. \& Feráková V. (2015): Red list of ferns and flowering plants of Slovakia, 5th edition (October 2014). - Biologia 70/2: 218-228. DOI: $10.1515 /$ biolog-2015-0018

Hadač M. \& Terray J. (eds.) (1991): Kvetena Bukovských vrchov. Príroda, Bratislava.

Jędrzejko K., Rahmonov O. \& Banaszek J. (2013): Flora naczyniowa (Tracheophyta) cmentarzy w Czeladzi. - Prace Komisji Krajobrazu Kulturowego 22: 77-88. [In Polish with an English summary]

Jehlík V., Májeková J. \& Zaliberová M. (2013): New discovered adventive plants from eastern Slovakia. - Thaiszia - J. Bot. 23(1): 61-66. 
Kollár J., Šimonovič V. \& Balkovič J. (2009): Sonchus palustris [report]. - In: Eliáš P. jun (ed.): Zaujímavejšie floristické nálezy. - Bull. Slov. Bot. Spoločn. (Bratislava) 31/2: 119. [In Slovak]

Kosiński P. (2010): The genus Rubus in the Bardo Mts (Central Sudetes). - Dendrobiology 63: 77-98.

Matthews J. F. \& Levins P. A. (1985): The genus Portulaca in the southeastern United States. - Castanea 50(2): 96-104.

Kurtto A. \& Weber H. E. (2009): Rubus. - In: Kurtto A. (ed): Rosaceae. Euro+Med Plantbase - the information resource for Euro-Mediterranean plant diversity. Published on the internet http://ww2.bgbm.org/EuroPlusMed [accessed on 6 September 2019].

Mirek Z., Piękoś-Mirkowa H., Zając A. \& Zając M. (eds.) (2002): Flowering plants and pteridophytes of Poland, a checklist. - W. Szafer Institute of Botany, Polish Academy of Sciences. - Kraków, 442 pp.

Murín A. \& Májovský J. (1976): [Report], pp. 487-488. - In: Löve Á. (ed.), IOPB Chromosome number reports LIII. - Taxon 25/4.

Nobis M., Klichowska E., Terlević A., Wróbel A., Erst A., Hrivnák R., Ebel A. L., Tikhomirov V. N., Byalt V. V., Gudkova P. D., Király G., Kipriyanova L. M., Olonova M., Piwowarczyk R., Pliszko A., Rosadziński S., Seregin A. P., Honcharenko V., Marciniuk J., Marciniuk P., Oklejewicz K., Wolanin M., Batlai O., Bubíková K., Choi H. J., Dzus M. A., Kochjarová J., Molnár A. V., Nobis A., Nowak A., Otahahel'ová H., Óvári M., Shimko I. I., Shukherdorj B., Sramkó G., Troshkina V. I., Verkhozina A. V., Wang W., Xiang K., Zykova E. Y. (2019): Contribution to the flora of Asian and European countries: new national and regional vascular plant records 8. - Bot. Lett. 166/2: 163-188. https:// doi.org/10.1080/23818107.2019.1600165

Euro+Med (2006-): Euro+Med PlantBase - the information resource for EuroMediterranean plant diversity. Published on the Internet http://ww2.bgbm.org/ EuroPlusMed/ [accessed 20 October 2019].

Májeková J., Letz D. R., Slezák M., Zaliberová M. \& Hrivnák R. (2014). Rare and threatened vascular plants of the railways in Slovakia. - Biodiv. Res. Conserv. 35: 75-85. DOI 10.2478/biorc-2014-0024

Marhold K. \& Hindák F. (eds.) (1998): Checklist of non-vascular and vascular plants of Slovakia. [Zoznam nižších a vyšších rastlín Slovenska]. - Veda, Bratislava, 687 pp.

Medvecká J., Kliment J., Májeková J., Halada L'., Zaliberová M., Gojdičová E., Feráková V. \& Jarolímek I. (2012): Inventory of the alien flora of Slovakia. - Preslia 84: 257-309.

Pliszko A. \& Jaźwa M. (2017): Floristic composition of vegetation in habitats suitable for Erigeron $\times$ huelsenii (Asteraceae). - Acta Bot. Croat. 76(1): 9-14. DOI: 10.1515/ botcro-2016-0040

Pliszko A. \& Kostrakiewicz-Gierałt K. (2018): The morphological intermediacy of Erigeron xhuelsenii (Asteraceae), a hybrid between E. acris and E. canadensis. - Turk. J. Bot. 42 (4): 543-550. doi:10.3906/bot-1711-27

Thiers B. (2019+) [continuously updated]: Index Herbariorum: A global directory of public herbaria and associated staff. - New York Botanical Garden's Virtual Herbarium, New York. - Published at http://sweetgum.nybg.org/ih/

Tokarska-Guzik B., Dajdok Z., Zając M., Zając A., Urbisz A., Danielewicz W. \& Hołdyński C. (2012): Rośliny obcego pochodzenia w Polsce ze szczególnym uwzględnieniem gatunków inwazyjnych. - Generalna Dyrekcja Ochrony Środowiska. - Warszawa, $196 \mathrm{pp}$.

Trávníček B. \& Zázvorka J. (2005): Taxonomy of Rubus ser. Discolores in the Czech Republic and adjacent regions. - Preslia 77: 1-88.

Zieliński J., Kosiński P. \& Tomaszewski D. (2004): The genus Rubus (Rosaceae) in southeastern Lower Silesia (Poland). - Pol. Bot. J. 49(2): 161-180. 